\title{
A sociological approach to the concept of God amongst Iranian youth
}

\begin{tabular}{|c|}
\hline $\begin{array}{l}\text { Authors: } \\
\text { Mina Safa } \\
\text { Habib Ahmadi }^{1}\end{array}$ \\
\hline $\begin{array}{l}\text { Affiliations: } \\
{ }^{1} \text { Department of Sociology, } \\
\text { Shiraz University of Iran, Iran }\end{array}$ \\
\hline $\begin{array}{l}\text { Correspondence to: } \\
\text { Mina Safa }\end{array}$ \\
\hline $\begin{array}{l}\text { email: } \\
\text { safamina@yahoo.com }\end{array}$ \\
\hline $\begin{array}{l}\text { Postal address: } \\
103 \text { Aria Street, Shiraz, Irar }\end{array}$ \\
\hline $\begin{array}{l}\text { Dates: } \\
\text { Received: } 24 \text { Feb. } 2010 \\
\text { Accepted: } 01 \text { June } 2010 \\
\text { Published: } 29 \text { Mar. } 2011\end{array}$ \\
\hline $\begin{array}{l}\text { How to cite this article: } \\
\text { Safa, M. \& Ahmadi, H., } \\
\text { 2011, 'A sociological } \\
\text { approach to the concept } \\
\text { of God amongst Iranian } \\
\text { youth', HTS Teologiese } \\
\text { Studies/Theological Studies } \\
67(3), \text { Art. \#809, } 12 \text { pages. } \\
\text { DOI: } 10.4102 / \text { hts.v67i3.809 }\end{array}$ \\
\hline
\end{tabular}

(C) 2011. The Authors. Licensee: OpenJournals Publishing. This work is licensed under the Creative Commons Attribution License.
One of the most fundamental concepts in Sociology of Religion, the concept of God, was emphasised in this article. Although the God concept is not the same as the transcendental existence of God, it is this concept that is the most fundamental social construct in the entire history of world religions. The aim of this article was the conceptual reconstruction of God amongst the youth of Iran, who may be free from a theological approach. This article aimed to examine the God concept in the 'epistemological', 'emotional' and 'social action' domains. The Iranian society is in transition, faced with delusion about the traditional and modern belief systems, and multiplicity of interpretations and new presentation of One God Allah. A spectrum of these plural presentations of God embodies micro and macro social levels. Some of the most important of these concepts are: individual and personal concept of God, the God in family, in educational system, in religious rituals, and the dominant concept in the society.

\section{Introduction}

The concept of God is one of the most fundamental ideas of human existence. Human beings, whether pious or pagan, have been challenging this concept consistently in solitude or in the midst of their social lives. One can categorise the entire history of human thought along the line of 'the meaning and concept of God'.

However, it seems that the concept of God has not been given due consideration by contemporary sociologists. According to Stark, this mistake occurred when Durkheim and other primary functionalists did not consider gods as an important issue and instead emphasised on rituals and ceremonies as the fundamental subject of religion. This viewpoint was soon transformed into sociology of religion's exclusive viewpoint (Stark 2003:B4). For instance, David Martin believes that a sociologist should neither speak nor write about God. However, in contemporary studies the new challenges have emerged, confronting such viewpoints (Young 1992:12). Notwithstanding the essential role that God had played in the history of Persian civilisation (now Iran) and to understand the present socio-political conflicts of Iranian people, the study of the re-emergence of God in contemporary social development is necessary. Particularly because the modern scientific 'Theory of Creation' has not yet been discussed by the Islamic theologians of Iran, there is this necessity.

The social history of Iran is divided into four historical periods:

- Sassanid (224-651 BC)

- Safavids (1501-1722 AD)

- The Constitutional Revolution (1905-1911 AD)

- The Islamic Revolution of 1979.

Sassanid originated with religious clergy, who introduced Zoroastrianism as the official religion of the people of Persia (now Iran). The magi acquired an eminent place in society. After the Arabic invasion in 700 AD, Islam became Iran's official religion. During the rule of Ommiads and Abbasids dynasty, Iranians were under Arabian dominance. In the Abbasids Empire, the Sunnite formed the majority of Iran's population and the Shi'ite had scattered, becoming a minority in Iran. Since then, Islam became the source of public and political governance in Iran and the Islamic concept of God was enforced in all affairs of society, not only in its theological discourses, but also in jurisprudence. The religious disputes between the Sunnite and the sect of schematics were also hyped during this period. In Iran, the schematics sect, which is a philosophical school, supports the official Shi'ite theological doctrines (Spuler 1995:45).

In the years (1501-1722) the Shah Ismail Safavi declared 12 Shi'ite Emami as the official religious Chiefs of the government and forced the people to accept the new Faith (Spuler 1995:45). The Safavids gained the legitimacy and authority by claiming that they have a divine right to rule. 
However, the clergy of the 17th century challenged the power of the divine monarchy and the radical obscurity of sectarian Islam regarding the legitimacy and authority of the rulers (Foran 1993:25).

The Constitutional Revolution in the Qajar period (1749-1925) resulted in ideological and philosophical debates about the new scientific ideas resulting from the exchanges with the peoples from the developed world. The Constitutional Revolution is, in fact, the first direct confrontation between traditional Islamic culture and the modern knowledge derived from the involvement of those from the developed world. This revolution challenged the cultural congruence of the traditional belief system and disagreements arose amongst the theologians, leading to new social, religious and political regimes. Whilst Ayatollah Tabatabaei favoured the new constitution, others, like Sheikh Fazlullah Nuri, tried to oppose this constitution reforms.

In 1979, after the victory of the Islamic Revolution, a new generation of students, with a new approach towards religious issues, came to the front. In this period, the influence of the developed world against religion and soulsearching amongst the Iranian intellectuals became evident. Scholars like Abdolkarim Soroush and Mojtahed Shabestari propounded new and different religious interpretations of Islam.

The contemporary society of Iran, although in transition, is still a religious society with a dominant Shi'ite Islamic cultural tradition. In our social and political structure we witness the clear dominance of religion over the government. The existence of 30 Shi'ite references of imitation in Najaf and Qum and reform were all influential in forming the God concept. On the other hand, modernisation and globalisation are the factors that challenge and weaken traditional identities (Hall and Held 2003:264). The youth are more exposed than other generations to these cultural influences from the developed world. Therefore, it seems that a religious sociology assessment, especially the changes in the religious expressions of the youth, would help in the analysis of sociopolitical changes. In this article, God is emphasised as one of the most fundamental sociological concepts of religion. 'God' is one of the most powerful social, cultural and humanistic precepts around the world. Historically, it had been a vital determinant factor in the societal relationship structure (Young 1992:12). However, there is a difference between the human perception of God and the reality of God himself (Armstrong 1993:40).

The target of this article, the conceptual reconstruction of the concept of God amongst the youth, was the city of Shiraz. Thus, the questions introduced in this article were: How does the concept and perception of God function in the subjectivity of youth? What changes are formed in the youth's subjectivity of God? What are the sources of these changes? How does the youth evaluate consequences of these changes? The aim of this article was to answer these questions by using a sociological approach, also benefiting from one of the qualitative research methods, grounded theory. Shiraz is the capital of Fars province, located on the south-west of Iran. This city is one of the biggest and most beautiful cities in Iran and has been Iran's capital city time and again. Shiraz is the 3rd biggest city and the 4 th most populated city in Iran. This city has many tourist attractions, is known as Iran's cultural capital and is also the home of tomb poets such as Hafez and Saadi. Shiraz has always been one of Iran's most important tourist centres and with its many historical attractions, is familiar for national and international tourists.

\section{Conceptual framework}

In the sociological approach, the question is introduced whether there is a causal relationship between the concepts of God and the social construct. Many believe that the source of the concept of God exists in society and that this concept is created directly by people's experiences of society (Bowker 1973:74). Comte, in his three stages, believes that how these concepts are understood depends on the stage that the society is in. From the Marxist perspective, the concept of God is a part of the ideology of dominant groups and social classes and that the understanding of it is also influenced by the social classes (Ritzer 2006:15). Swanson argues that a nation's specific experience in different social conditions is responsible for creating various concepts of supernatural or spiritual existence. He states that to understand a nation's specific religious concepts, we have to explore some of the characteristics or fundamental relations in their social organisation, (Hamilton 2001:152). Regarding the social construct and the concept of God, Berger claims that social conditions are considered a framework for the cognitive condition of the concept of God. He believes that there is a dialectic relationship between an individual and the concept of God and also mentions that the concept of God is in need of specific social plausibility structures, which are necessary for maintaining it. One of the most important plausibility structures about the concept of God is conversation. In everyday life, there is a social conversation system that consistently maintains, alters and rebuilds the concept of God (Berger 1967:100). Berger's opinion is that individuals' religious identity and the concept of God that they behold is significant in a certain social environment, which confirms this concept and identity. This significance is evident in religious rituals and the significant relationships that they have with their religious society. Thus, the perpetuation of a concept of God needs a religious community and to live in a religious world needs integration with that society (ibid). The concepts of God influence the structure of social organisations (Warrick 1999:12). These concepts can be a symbol of an unavoidable humanistic progress and also of God, who legitimises the models of economic, cultural and social class system's power (Ziebertz 2001:78). The concept of God has consistently influenced the concept of human beings. Any definition or concept that human beings have about God in different historical, cultural periods and societies influences the definition and concept of mankind. In fact, human beings mark part of their psychological, cultural and social identity by the collective concept that 
they have of God in a specific historical period. In any case, there are positive and negative evaluations of the concepts of God in this relation. As Nietzsche and Sartre state, the lack of the concept of God results from the lack of a fixed concept of an individual (Zibert 2007:80). In defining the God of authoritarian religions, Fromm believes that as much as God is considered as the omnipotent and omniscient in these religions, humans are considered as weak and inferior (Fromm 1967:34). However, evaluations of the concepts and images of God were not always so pessimistic. Many believe that the concept of God in Abrahamian religions lead to the formation of an image of humanity that deserves freedom, equality and other human rights (Armstrong 1993:200).

The political influences of the concept of God can be seen in different periods in history. Griffin believes that the supernatural concept and conception of God, that has been dominant in the modern era, can control human affairs unilaterally and be utilised to support the existing status quo. For instance, the divine right of emperors in the Roman period was confirmed by resorting to this conception of God (Griffin 1989:171). In Iran, power was considered a divine blessing. This concept of a divine essence and the idea of unity between religion and kingship was the basis for the political thought in Iran before the Constitutional Revolution, so much so that the sanctification of emperors in Iran reflected the divine power. The concept of God has had great influence in the formation of the cultures and subcultures of different nations. Warrick states that the ideologies and different concepts of God have linked with religious traditions to create the culture of any nation. But the concept of God has also been the cause of cultural tensions, hatred, mistrust, war and violence. There is a significant relationship between collective belief in God and the social and cultural value system that results in violence, for example, the Shia and Sunnie violence. Therefore, from the cultural perspective, the concept of God is consistently situational (Warrick 1999:13).

It seems that it is as a result of this cultural situation that the monotheistic religions tend to have prejudiced and illogical intolerance towards 'other' minorities (Backford 2003:36). This means that every group or assembly defines some others as enemies or opponents and exclude them from 'us' and thus 'the enemies' are not entitled to equal human rights. This attitude becomes 'ethics' and accordingly, other human beings can be killed (Warrick 1999:12-14). Therefore, believers in one God may have violent confrontations when faced with the followers and believers of a different God. From the historical assessment of God, it can be concluded that like all other social concepts that is created over generations and by specific individuals, the concept God can be meaningless for different generations and individuals (Armstrong 1993:1; Odwazny Peterson 2005:4).

There are many historical factors contributing to the concept of God, but in the present period, scientific modernity is the most important. With modernity, rationalisation and secularisation have affected the people of Iran, as a scientific, secular perspective is most likely to lead to a decline in faith healing. It is interesting to observe how much religion and God still influence or control the cultural and social evolution (Hall \& Gieben 1992:230). One of the most important methods in reflecting on concepts of God is discovering their survival value in the selective and adaptive process of evolutionary dynamic periods (Bowker 1973:110). Earlier, Berger believed that 'the crisis of credibility' occurs because human beings are consistently searching to understand what the characteristics of God are, in order to be Almighty (Berger 1968:126-132) The crisis of credibility means that each generation creates a concept of God according to the cultural and political need of the times. The functionality of the concept God is much more important than its rational or scientific aspect. So, any concept of God that loses its function must change (Armstrong 1993:2). Considering the explanations presented, in this article the concept of God in the minds of the youth was explored.

\section{Methodology and results}

In this research, 73 individuals between the ages of 15 to 28 (averaging 18.2) from Shiraz participated. Of these, $60.27 \%$ were female and $39.7 \%$ male. There were $54 \%$ high school and $46 \%$ university students. All participants are Muslim and Shi'ite and have been residing in Shiraz at least since 10 years ago. Of the participants, $90 \%$ were single and $10 \%$ married. Regarding their social status, $68.5 \%$ were from the middle class, $19.17 \%$ from the higher class and $12.33 \%$ from the lower class. Shiraz was selected because it is a metropolitan city with transitional conditions from traditional to modern and the influence of modernity and globalisation can be seen in it. The existence of plural religious identity resources, new and various reference groups and also the researcher's familiarity with its social context also contributed to the choice. The research data was collected between March 2006 to February 2009 with an open and in-depth interview method. The researcher, who is Muslim and Shi'ite, experienced in teaching in university and high school and is obliged to research ethics, has been capable of establishing close and friendly relationships with young people and attracting their attention. However, prior to the beginning of interviews, the researcher had observed educational environments and talked to teachers, professors, counsellors and parents. Initially, samples was chosen according to the research questions and purposes, based on characters such as:

- being Muslim and Shi'ite

- being 15-29 years of age

- being in the social level of the middle class

- studying at high school or university

- residing in Shiraz for 10 years or more

- wanting to participate in the study

- being able to express their thought and emotions.

Their places of study were high schools and universities in the centre of Shiraz city. After several interviews and simultaneous data analysis, sample taking was continued, but based on more specific characteristics, such as the students and their families' religiosity, existence of an intense feeling of guilt, background of deviant behaviours, previous 
failures, illness and political oppositions. In this study, 60 in-depth personal interviews and 4 focus group interviews were performed until the researcher obtained theoretical saturation. Most interviews were audio taped and then transferred to paper. The researcher aimed at discovering the theoretical relationship of the concepts and subjects and analysed data through open, selective and axial coding and constructing categories and core categories. The result of this study was presented in six core categories which are as follows:

- epistemology and the concept of God

- Anthropomorphic concept of God

- emotional orientation in the concept of God

- expectations from God

- the individual and personal concept of God

- the society's concept of God.

\section{Epistemology and the concept of God}

For some participants in the study, expressing concepts and images of God were somehow accompanied by a feeling of guilt. For another group, discussion about God aroused various philosophical, religious and social questions: 'I have many forbidden questions about God ... Why was I created? Who is my God? What was the wisdom behind my creation?'.

Although the participants thought that their questions are nonexpressions and sometimes forbidden, they have an intense need and enthusiasm to ask their questions and find answers. A considerable number of participants believed that they should avoid thinking or asking questions about God. One of their reasons is the incapability of a human being's cognitive and mental capacity for understanding complex and infinite issues such as God, death and the afterlife: 'They say you don't understand these things, they're complex... A human's mind does not have the capacity to understand the greatness of God ... I can't understand it'.

A number of participants claimed such thinking; presenting and even listening to such questions caused anxiety, disturbance, giddiness, confusion, fear and feelings of guilt. Also, many participants believed that thinking about God would push them to insanity and madness, as evidenced by the following extracts from interviews:

- 'I feel scared when I think about God. My mind blocks and I can't speak'.

- 'I feel dizzy and lost ... a feeling of explosion and darkness of the mind ... I don't like to think about who God is because I don't know the answer and I feel irritated'.

- 'When I think about these things my mind undergoes error and hangs'.

- 'By thinking about the essence of God, etc. my brain explodes and reaches a dead end and experiences insanity'.

- 'When I think about God, my mind is disturbed, I don't like to think too much about God, because I reach the limits of insanity'.

- 'They say you shouldn't think about the nature of God because you will not reach an answer and you will go crazy and so we voluntarily don't think about God in order to avoid becoming pagan'.
Regarding this matter, it seems that the participants preferred to have an emotional and relational orientation about God. However, rational and epistemological orientations were unknown, vague, inaccessible, scary and threatening for them. Some of the participants believed that talking, thinking or questioning about God is a sinful and evil act and for this reason, they forbid themselves and others to enter that field:

'Thinking about God and where he comes from ... is an evil thought... I try not to think about these things because it's a sin, we shouldn't be too curious about God.'

(Participant in study)

Some of the participants mentioned that the reactions of educational institutes, family, friends and the understanding and interpretation of religious teachings are the reasons for such viewpoints:

'If you say something wrong in a mosque, it's really wrong, they
don't allow discussion about religion, Any time we tried to talk about
who God is at school, the teacher said we are pagan ... We had many
questions about God and older people said it's a sin and you will upset
god and you shouldn't ask about God.'

(Participant in study)

At any rate, the kind of questions that are sinful is not obvious and the fields that are sinful and evil to ask questions about are not determined. According to the interviews, it seems that for young people, who have access to more reliable religious sources, thinking and questioning about God, can strengthen their faith. For others, these questions can weaken their beliefs and religious faith and keep them away from God: 'My questions about God have weakened my faith in him'.

It seems the taboos and labelling the questions about God as sinful and pagan has created fear in the youth, so much so that the possibility of presenting rational issues in philosophy and religion is faced with serious obstacles. Moreover, many questions that are related to God are not just associated with the nature of God but also with theological, philosophical and social criticism. As a result, the social and mental restrictions for asking such questions has deprived the youth from the opportunity of social criticism. In fact, the fear of asking questions about God that has social dimensions is the fear of criticising the world and the society.

\section{Concept of human}

With regard to epistemology, the concept of God in the minds of the participants was also associated with and consisted of the concept of human nature. Some participants believed that God has created mankind as the superior of the creatures and the best of all the creatures, even angels and that all the other creatures were created for mankind:

'Mankind is the best and most superior of all creation, whatever God has created was because of us, God is totally pure and since we are from God, so are we'.

(Participant in study)

Human beings were sometimes regarded as having a good nature and were sometimes considered bad and sinful against God. The logical result of believing in the common divine and godly source in the creation of mankind is also the 
similarity of the essence of all human beings, their equality in God's eyes and the sameness of their needs and necessities: 'Because I believe in God, I realised that I' $m$ equal to others, whether black or white, beautiful or ugly, we are all human and our needs are the same'.

The considerable point of relation to the concept of God and the concept of humanity were the issues of freedom and free will. Most of the participants did not grant any freedom or free will to human beings against God and they believed that human beings don't have the power to choose or change anything. Belief in destiny was clearly prominent and observable in the interviews. The participants believed that the fate and destiny of human beings was predetermined by God and that human being cannot challenge their destiny:

'I think human beings don't have any free will ... People can't change anything ... I suppose I'm free but I can't stand against my own destiny ... He controls my destiny and he can take me anywhere, the fate and destiny of each and every one of us is in his hands and he has predetermined our fate.

(Participant in study)

The participants also mentioned and talked about the purpose and aim of the creation of the universe and human beings in their mental definition of God. There are many participants who recognised God as the meaning of their world and their life, believed that life without God would be meaningless and vain and that God's purpose with creation was for it to worship him: 'Life without God is futile and vain, the sky without God is meaningless'.

One participant even said: 'If there was no God, I would have commit suicide a thousand times by now!'.

However, another group stated that, although they accept and believe that God had a reason for creating the universe, especially human beings, they do not know what this purpose is. When confronted with this lack of understanding about the aim of God, they became nervous, disturbed and lost. Here, the lack of understanding of the purpose of God in creating mankind is not the only important issue; the more important issue for each person to understand the aim of his or her creation.

\section{The anthropomorphic concept of God}

Many participants in the study reported some 'personalised' and 'anthropomorphic' conceptions of God, especially in their childhood period. In this conception, God has ideal manlike characteristics:

'God is a normal being just like people and he's very beautiful and kind ... a greater human being with infinite intelligence ... He has great perception and conception power...Maybe he is an extraordinary man with an innocent complexion, very kind and patient who never gets old.'

(Participant in study)

Here, the image of God as an old man with a long, white beard, which is a relatively dominant image influenced partially by his grandfatherly and patriarchal role, tends towards the mental image of a middle-aged man. This change could be the result of the changing role of the father in the family. In the analysis of anthropomorphic conceptions of God, we were also faced with the influences of the society's dominant culture and religious tradition. The concept of God in the subjectivity of the participants was sometimes in the form of an emperor, lord or judge. The imagining of God as a lord or emperor can reflect the political power structure in the social history of Iran. The lord conception is of one who has absolute power and wealth. Here a combination of the social benefits of wealth, power and social statue is observed in the absolute and unconditional form of imagining God as a king or lord. Moreover, in the mental conception of a considerable number of the participants about God, images and conceptions of Arabic men and clerics was also noticed. For instance, such images sometimes showed men with long white beards wearing a cloak:

- 'A great tall man who is old with a white cloak and a long, white beard'.

- 'A man with a brown cloak ... A man with a bright face and Arabic clothes'.

- 'A man with a green cloak with big eyes and beautiful rough eyebrows ... a picture of Arabic men which I have in my mind'.

It is interesting that all these mental conceptions are of Arabic men and not of Arabic women.

A considerable number of participants stated that whenever God was mentioned, they had a picture of Imam Khomeini (the deceased leader of the Islamic Revolution of Iran), especially in their childhood:

- 'I imagined God in the form of Imam Khomeini for the first time... When I was three years old I though God was similar to Imam Khomeini ...'

- 'When I looked at Imam's picture, I remembered and thought about God or when I heard the name of God, Imam's image came to my mind ... Because you could find traces of God in his character.'

It seems that one of the most important reasons for such a mental conception is the connection between Imam's personality and the concepts and definitions that the youth had heard or experienced in their childhood about God. Sometimes it was even the image of an ideal human being which was projected as the concept of God. Therefore, on the one hand, humanistic images of God are seen and the human characteristics in the mental concept of God are seen in the participants on the other hand. Also, such an anthropomorphic concept of God is generally found in the form of parents, men and other symbols of social power.

\section{The concept of God and the image of parents}

From what was observed in the interviews, it is clear that the family has a key role in creating the concept of God, especially in childhood. The concept of God in childhood has a more materialistic and physical identity and abstract conceptions are extremely rare or absent. These conceptions also consist of anthropomorphic, close, tangible and accessible conceptions 
of God. Anthropomorphic images of God are very similar to images of mothers or fathers or sometimes grandmothers and grandfathers, generally the people responsible for taking care of a child. It seems that factors such as the mental images of parents, feelings towards them, manner of understanding and interpreting parents' emotions or opinion of their children have a great influence in creating mental concepts of God in childhood. The type of relationship children have with their parents and also the understood characteristics of parents by children, including love, friendship, kindness, forgiveness, care, blandishment and even authority, power and strictness, also adds to this influence. With respect to this matter, many characteristics that are attributed to God are motherly characteristics such as unconditional love and affection, blandishment, care and attention. Moreover, other features like power, strictness and sometimes violence or aggression arise mostly from the relationship to their fathers. In any case the formed mental conception of God in childhood is mainly an ideal image of the characteristics of a very good mother or father and if this image does not correspond to a child's real parents, it shows his or her expectations from God and the parents. In addition, children's religious socialisation can be specifically mentioned. This process is influenced by the family's theological instructions or their religious or nonreligious behaviour and it is related to the type of family structure. It seems that in this relation the participants' experience can be categorised from family structure and relationships. There are 'religious families' who consciously or intentionally try to teach the concepts of God or religious rituals to their children. This group can be divided into two: 'democratic' and 'coercive' religious families.

In 'democratic religious families', which respect the personal and individual freedom of members and give the family members the opportunity to think and contemplate about religious beliefs, the instructions are not forced and the respondents experience freedom to choose, intimacy, love and respect: 'In my family everybody believes in God, each person has a certain viewpoint and nobody is strict ... my father gave me the opportunity to find my God freely'.

It seems that although 'democratic religious families' give the opportunity to think and choose right from wrong to their children, they tend to guide children towards a concept of God that they believe in.

In 'coercive religious families', respondents reported experiences of protective reactions, such as acting impertinent and rejecting the family's concept of God. In some cases, although the children believe in God, they have a tendency towards hidden faith as a result of this stubbornness, in order to challenge the family's authority.

Another type of family is the 'non-religious coercive family'. In these families children are not allowed to ask questions about God or religion and they also can not go to holy places or participate in religious rituals: 'In my family my father doesn't give us the opportunity to talk about God ... We were not allowed to go to mosque'.
In the interviews, another type of family was also observed, the 'non-religious godly family'. In these families, the members believe that loving God is enough and they do not think that religious rituals are necessary to have a good relationship with God:

'My family believes in God, but we are not religious ... In modern lives God can be seen in most families... They don't pray but they have a deep belief in God'.

(Participant in study)

Some interviewees came closer to God by 'experiencing separation from parents'. It seems that the temporary or permanent detachment from the safe relationship with parents leads to a feeling of insecurity and solitude, which can bring them closer to God in a compensatory mechanism. This need for replacement is taught, even before being experienced:

'My mother always used to say God is always with me in order to reassure me and free me from the fear of leaving them. She used to say God will always protect me, so I won't have to worry'.

(Interviewee)

Here, the concept of God is a replacement for the care and security that parents provided for their children. But, in the participants' real experience, some cases have been reported in which they had really experienced this separation and detachment:

'When my mother punished me I remembered God more ... When I didn't speak to my parents or siblings, I cried under my blanket at night and talked to God'.

(Participant in study)

Separation from parents can also occur by losing them. In this case, the father and mother are usually replaced with God and children feel that the responsibility of loving, caring for and protecting them is transferred to God. Detachment from parents may also occur by the reaching of adolescence, because teenagers feel that their parents cannot take care of them or be their protector any more and although the parents exist, they still feel lonely and insecure. Generally, it seems that families have been driven towards the pluralism of beliefs and religious presumptions, especially the pluralism of the concepts of God. Thus, the congeniality and homogeneity of beliefs and religious concepts is declining in families. Also, with the gradual change in the family structure and the weak presence or absence of grandmothers and grandfathers in nuclear Iranian families, the image of the grandfather as a God is gradually fading. Although Iranian families still have a patriarchal structure, it seems that a more equal relationship between the authority of men and women is developing.

\section{Gender orientation}

In the anthropomorphic concepts and images of God, three main orientations (masculine, feminine and androgyny concept) could be observed amongst the participants. The masculine was dominant, the feminine to some extent considerable and the androgyny concept at the minimum level of consideration. Most participants in this study, both male and female, had a masculine image of God in their minds. The character of this mental image was mainly 
reported as a father, sometimes grandfather, king, lord, cleric, judge, mystic or even a commander. The important point in the respondents' statements was the reasons for having a masculine conception of God. One of the reasons participants mentioned in this regard is the existence of masculine names for God. Moreover, in their interpretation and belief, men have more physical and mental power and ability compared to woman and because one of the characteristics of God is unconditional authority, power and ability, he cannot be feminine:

'God is a man who can do anything he wants ... He is a male who can do all these things ... I think he is a man, because he isn't afraid of anything'.

(Participant in study)

Some participants mentioned that their reason for their masculine conception of God was the fact that he is more righteous, less emotional and that his has ability to express anger:

'I feel that he's a man because they say that men are more righteous and they're not sensitive in facing problems. Only men can become angry and show their anger. For instance when an earthquake occur God is showing his anger to mankind .... In my mind God is a man'.

(Participant in study)

However, more importantly, there were some female participants who stated that the prejudice and difference that they believed to be in the creation system and therefore, in the society and social relationships between men and women were the source of their masculine conception of God. From their point of view, boys and men have more freedom and fewer restrictions in their society and discrimination and prejudice is high between men and women. God has given men more facilities, freedom, benefits, advantages and mental and physical ability:

'God is a very kind man who has given men more advantages, more intelligence and physical power and fewer emotions ... I think God is a man because in Islam and in the society all advantages are in favour of men ... God is very strict when it comes to woman and has given them hard duties ... He has given most hardships to women.'

(Participant in study)

In their opinion, God has assigned many difficult duties and restrictions for woman and many female participants claimed that if they were a man they would have a better emotional orientation and relationship with God. According to the responses, it seems that the masculine conception of God and the belief that God and creation is responsible for social prejudice and discrimination against woman can deepen and strengthen the inequality and prejudice against woman. This, in turn, can lead to ineffective civil efforts to eliminate such prejudice.

\section{Emotional orientation in the concept of God}

The participants reported specific and sometimes contradictory feelings towards God. The most important were feeling guilt, fear, excitement, prosperity, hope, happiness and shame. The most prominent feeling was an individual's guilt against God.

\section{The concept of God and the feeling of guilt}

The results of the interviews showed that the youth's conception of God forms the manner with which they confront guilt. Also, their conception of guilt forms various and sometimes contradictory concepts and images of God. It seems that many participants in this study experienced some kind of 'basic feeling of guilt' regarding God. Sometimes the cause of this feeling was the understanding of God's greatness, unconditional power and his supervision and control. Usually, the participant's reaction to understanding God's unconditional power was a feeling of weakness. In that way, sometimes this feeling of guilt was not accompanied by the external proof of sinfulness. One of the participants said: 'A feeling always tells me you should always be ashamed of God, I search for a wrong doing within myself but I don't find proof of any sins'.

Moreover, their understanding and interpretation of the consequences and punishments that God will apply against their sins in this life and the afterlife can be the cause of their anxiety and tension, which, in turn, is a caused by a feeling of guilt. According to such feelings of guilt, the participants had different conceptions of God. One of these images was the strict, scary and revengeful God, who does not forgive sinners easily. The effects of these punishments were seen as people's illnesses, problems and suffering in this life and as hellish tortures and sufferings in the life after death. So much so, that individual and social problems and sufferings were considered to be the consequences and punishment of their sins:

'I think that anyone who's suffering from an illness is due to a sin they have committed and the suffering is a reaction to their sin ... Bam's earthquake was God's warning to their wrong doing'.

(Participant in study)

Another conception that was observed, mostly amongst teenagers, was the conception of a very kind, permissive and nonchalant God, who understands them and easily forgives their sins and mistakes: 'He's so kind and forgiving that it's not important for him whether I pray or not or whether I'm Muslim and wear a veil or not'.

However, a small part of the participants had an ethical and responsible conception about their feeling of guilt. They felt that they were responsible for their actions and unlike the first two groups, interpreted specific behaviours as wrong and sinful. In such conditions, the feeling of guilt can thus be the source of 'an ethical feeling' in the youth. The participants in this study had different experiences of guilt in their childhood, adolescence and youth. Most participants remembered a feeling of innocence and a close and calm relationship with God in their childhood. However, it seems that the feeling of guilt regarding God was truly felt and formed or aggravated in adolescence. It is probably for this reason that many participants thought that God was distant from them or did not pay attention to them in adolescence: 
'When I became older I felt God doesn't like me like before ... I am very distant from god now feel guilty, God doesn't love me anymore and doesn't protect me. He doesn't restrict me from sin like before'.

(Participant in study)

In many participants their feeling of guilt was often accompanied by negative feelings such as self-hatred, worthlessness, humiliation, weakness, uselessness, internal shame, self- reprimand, solitude and generally a negative mental image of themselves. In some cases, these feelings were accompanied by a tendency towards suicide. This hurtful feelings of guilt in some participants was so much that they were scared of confronting God because of their shame and fear:

'I'm ashamed of talking to God ... I want to be punished somehow ... but when I do something wrong and repent I feel God has forgiven me and I have a good feeling'.

(Participant in study)

This internal feeling of being punished by God as a result of committing a sin could perhaps be considered as a justification for the importance of sacrifice in religions. Therefore, it seems that there was a generally fundamental need in participants to 'feel forgiveness', especially God's and a need to 'feel pure and innocent'. Although the participants had a tendency to avoid sin to please God, some of them felt that being innocent was difficult or even impossible:

'Sometimes some of the things God has said they're necessary for becoming close to him are just not possible ... I don't have the power to bear some of the things he has said'.

(Participant in study)

Some participants believed that the difficulty and impracticality of some of God's desires and consequently, committing sin is as a result of social strictness and the social definition of sin. As it seems, the society has expanded the domain of behaviour and manners that is defined sinful, to the extent that the youth were not able to accept it and sometimes considered them in opposition to God's desire and religious commandments:

'The society says it's a sin to act against the law, but the Quran doesn't say so ... the principal says if you don't listen to the lesson it's sinful and forbidden if you bring a cell phone, it's sinful'.

(Participant in study)

Accordingly, it seems that the respondents could differentiate between the concepts of $\sin$ in God's eyes and religion's definition of sin. They also felt the society was stricter than religion and God. Feeling guilty in front of God had several social and individual consequences to the participants. The most important was the reaction of those who felt rejected and driven away by God. Their belief in God's nonforgiveness and nonacceptance lead to more detachment from God, the label of guilty and probably the continuation of those behaviours that were considered sinful:

'God forgives sins only once and if they are committed twice he turns away ... I am guilty so I rarely think about God ... I'm so guilty that I'm afraid to pray'.

(Participant in study)

It seems that regarding different individuals, the feeling of guilt has a specific limit and peak, beyond which there is not only no motivation for turning back and repenting, but that might also lead to the continuation of the behaviours that an individual considers sinful. In the social aspect, the youth felt lost in distinguishing right behavioural standards as a result of the very vast and specifically defined circle of $\sin$ in strict societies. Young people, who are not able to adapt to the values and norms and sometimes consider the disagreement to accepted social and religious norms inevitable, experience a deep and intense feeling of guilt. The internal sufferings of this feeling can drive God and religion away from their life and mind: 'Today's youth is tired and the pleasure of committing sin has multiplied for them'.

The practical result of these mental approaches can also increase social violence and deviations. According to their point of view, as at present they can not ignore the desires and needs of their youth, they neglect God's desires and religious commands. However, they still have feelings of guilt and being bad in most of their actions, which results in a very negative self-image. Another reaction that the youth expressed after feelings of guilt caused by the lack of adaptation to religious social norms, is the tendency towards other religious and sometimes a change of religion. Their rationalisation was that God's commands are easier in other religions. For instance, music, dance and relationship with the opposite sex, which are important issues to them are not forbidden and restricted in other religions:

'I don't like veil at all and because I didn't want to commit sin, I changed my religion... when I compare other religions I see how God judges their actions, for example, they drink alcohol but don't go to hell.'

(Participant in study)

One of the most powerful motivations for changing their religion was the need to be set free from feelings of guilt in front of God. In such cases, the youth used changing their religion as the mechanism to free them from the pain of feeling guilty. The feelings of guilt in young people have various other consequences, including the fact that although the person feels guilt, he or she feels that their social status and respect have declined. This issue itself influences their social relationships and connection status. Generally, carrying the burden of guilt in front of God is painful for most people and they have various mechanisms to cope, including repentance and asking for forgiveness from God, changing the definition of sin, their religion or their concepts of God.

\section{Human's expectations of God}

The respondents pointed out the expectations that they had from God, whilst expressing their mental image and conception of him. These expectations were sometimes so intense that some of them believed that it is a human being's right:

'In this world each person has the right to have a comfortable life from the economical and social aspects, etc ... and God has to prepare these things for people'.

(Participant in study)

From this perspective, it seems that the expectations that the youth have of God is something similar to the citizenship 
rights in modern urban societies. Moreover, the participants expected the merciful and compassionate God to provide health and welfare for all human beings and guide them towards right doings and heaven. Some expectations of God were formed according to the participants' concept of God. The more absolute the characteristics of God are, the bigger and sometimes impossible the expectations of him were in this world. Also, this extension and generalisation was accompanied by a kind of 'public benevolence' and a tendency towards world peace and friendship, in other words, the universal and, humanistic ideals and desires. These humanistic ideals were manifested in people's prayers towards God.

\section{The concept of God as a problem solving mechanism}

Besides the positive effects and functions that the youth expected of God regarding their religious responsibilities, it seems that the mental conception of most participants about God was formed mostly along issue of problem solving. In this orientation, the kind of problems and issues that drove the participants towards God were those that seemed unsolvable, vital, very important and unpredictable. These are problems and issues that individuals perceived to be beyond their tolerance and solving ability. The interpretation and perception of human beings about problems and the problem solving aspects it is constituted by in their minds, forms a specific conception of God. Also, the kind of problems that they expected God to solve, their own role in the process and how they defined this role had a very essential influence in this matter.

\section{Compensatory mechanism in the concept of God}

Taking into account the interviews about the concepts of God, fundamental compensatory mechanisms were expected by participants regarding their fundamental needs and desires. An important part of this compensatory mechanism was related to mutual relationships and social interactions. People are hurt in many social relationships or their relationships are threatened and in this regard, the most important damage that threatens their social relationships is feeling powerless and weak and they see its compensation in God. Form the participants' point of view, God compensates for the inequality and injustice of wealth, power and social reputation distribution in the society. He is the poor and deprived people's saviour and defends then against oppressors. God is also the compensator of a low social class and reputation. All people are equal in God's eyes, regardless of the defined social differences, and they are all treated with love and respect on his behalf:

'God is the only person who doesn't care whether you are poor or affluent, guilty or innocent ... a person who has been in difficulty in this life goes to heaven ... I might see his justice in the afterlife... Maybe I have to suffer here so I could be rich in the life after death... If there wasn't another world there wouldn't be any judgment day and I couldn't carry the burden of all this pain and misery'.

(Participant in study)
The acceptance and unconditional love of God to mankind gave them a feeling of worth and generosity and had an important role in compensating for the alienation and painful feeling of inferiority that they experienced in their social relationships. Additionally, believing that God punishes oppressors in the afterlife and that the deprived and dispossessed go to heaven, is a powerful social compensation mechanism and leads to higher social adjustment.

\section{The personal and private concept of God}

In the interviews, many respondents mentioned that the God they knew and worshipped was a personal, individual and private God. The concept of a personal God was limited to young people's personal and private life and understood and experienced in personal ways:

'I have an ideal God for me ... a God who I live with ... my God is only my God ... and is very distant from the God people have taught me'.

(Participant in study)

This personal and private God had unique characteristics, according to the individuals' different cognitive levels and features. Young people felt and understood him from their childhood, so that they did not differentiate 'self' identity from 'God's' identity:

'God is my unfound self, sometimes I confuse myself with God ... my God grew with my age, I have a 17-year-old God, now ... God changed me and he is still changing me now'.

(Participant in study)

This internal God undergoes change, just like a person's identity.

\section{The concept of God as an ideal friend}

The personal and private God has an intimate and friendly relationship with youth, he understands them and knows their needs and judges them fairly: 'God sees many good things which others don't ... He sees me and cares for me ... he knows us ... understand us ... he understands everything'.

This personal and private God was often thought of as an ideal friend, who had characteristics such as patience, secrecy, faithfulness, gratitude, intimacy, sympathy, love, acceptance and reliability. From their point of view, a friendly relationship with God did not have any of the social hazards of other friendly relationships. In a friendly relationship with the youth, God respects them, maintains their freedom and generosity and never blames or denounces them:

'He is the only person doesn't degrade me regardless of my faults ... he doesn't interrupt my speech and doesn't let my secret out or embarrass me ... Oh God! I can only tell my secrets to you without being blamed.'

(Participant in study)

The considerable suggestion from the interviews was that in some participants' experience this friendly relationship with God was similar to friendly and informal relationships between ordinary people, in a way that some even joked or huffed with God: 
'God sometimes speaks to me, huff ... sometime I joke and laugh with him ... I speak to him in a friendly manner ... I love you, I'll sacrifice myself for you, if it's possible listen to my prayers ... every night before bed I talk to him, even in my dreams I sometimes see him and talk to him.

(Participant in study)

In such a friendly relationship, discourse with God was comfortable, intimate and in a friendly and relaxed manner. The same kind of informal and nonritualistic speech was used as in an ordinary friendship between two people. Internal dialogues with God were sometimes in the form of arguments, objections and complaints:

'I talk to God and discuss matters with him ... When he doesn't fulfil my wishes I argue with him while praying ... I don't speak to him when I want something and he doesn't give it to me I argue with him ... I say: God! Why didn't you create a world where everyone is in welfare ... sometimes I'm not so sure about your justice and I know I shouldn't, so I repent many times.

(Participant in study)

Sometimes, these disputes and complaints were directed towards vaster social aspects. For instance, complaints about social inequality or injustice that they believed were rooted in the inequalities of the creation system, which was ultimately God's. Besides this, the participants expected to have a comfortable and affluent life when obeying their religious commands, otherwise they complained to God:

'Ever since I was a teenager, I have obeyed the Islamic rules, so I'm upset with God and I complain why? ... I have always argued with him about the sins I have committed ... Why wasn't I born in a wealthy family? Why can't I have a comfortable life just like others? What is the difference between me and them?'

(Participant in study)

The participants also talked about their 'individual and unique confrontation' with God in expressing their friendly and spiritual relationship:

'My God is different ... I think he only belongs to me. And he loves me more than others ... he pays a lot of attention to me , I know it's wrong but since I love him so much I can't accept that he would like anybody more than me.'

(Participant in study)

They thought that their God was unique and believed that this personal God paid more attention to them and loved them more than others. Some relational orientations with God, such as friendly and spiritual relationships, included people's unique conformations with God. Participants had personal and specific experiences of God from childhood. This concept was related to the formation of 'self' in a person, the identification process and also personality changes. Confrontation with God is unique, just like the unique confrontation of a human being with existence, the universe and the society.

\section{The social concept of God}

According to the interviews, there were fundamental differences between the individual concept of God (private space) and the social concept of God in the participants' mentality. They believed the God that the society presented was not real that and the internal and external God were different, in some cases, completely opposite. From the participants' perspective, the dominant image of God in the society was the image of an unhappy God, which is mainly formed in sad and sullen religious ceremonies and rituals that project it. They thought that remembering God in religious mourning, banning music, dance, fashion and happy amusements and excitements that the youth preferred and related to, these limitations on God had formed strict and boring conceptions of God and his opposition to happiness in the mentality of some youth. In other words, young people observed the image of God in a halo of sadness and sorrow and this God was absent in social joys and happiness:

'The society's God is seldom seen and we see him more in sad religious ceremonies ... God does not like happiness ... The society's God is cold, dry, rough and unfriendly'.

(Participant in study)

Along these lines, many participants stated that the 'observation' and 'partially oriented' concept of God that is present in the society had expanded the circle of sin. Many social and individual behaviours that the youth considered right and according to their real needs and desires or related to their very private life issues, were forbidden and sinful in this vast circle:

'If you touch her hair they say its sin ... God has forbidden it, whatever we do in the society God considers as sin ... The society says if you act against the law it's a sin but God hasn't said it in the Qur'an.'

(Participant in study)

In other words, they thought that the society defined the customs, laws and norms and considered any deviation from these laws as sinful in God's eyes, but the real religion and God did not. Accordingly, they believed that the society's definition of the circle of sin was vaster and more specific than that of the private and individual God and the domain of social limitations which were defined in the name of God and religion was vast and limiting. In this viewpoint, God has a punishing reaction to people and the name of God reflects pain, suffering and the fires of hell. Moreover, the encouragement of positive behaviour is either absent or rarely seen. This God does not give people a second chance:

'They say if you don't do these things that God has said, you will burn in hell and you are pagan ... he will hang you by your hair in hell'.

(Participant in study)

For this group of participants, the conception of the society's God was a tough and frightening one and the people's most important reaction to him was fear. Some of them believed that this tough and fearful image of God was opposed to the personal experience and loving relationship they had with him. They even thought that this God was also different from religious teachings, which presented God as the friendliest God:

'I have been forced to fear God ... Television and the surrounding environment present a scary image of God ... Adults have created a frightening image of God for youth'.

(Participant in study)

Another group of participants believed the society's God to be an oppressor and despotic. Such a God was an oppressive and obtrusive, possessing supernatural power, sacred, 
superior to people, dogmatic, rigid and resistant to criticism. For this kind of God, people had one-sided responsibilities and duties and he punished and restricted very strictly, without giving people any right to complain:

\begin{abstract}
'In the society God is thought of as a despotic king who ruins your life if you don't obey. Even if you do something good it is your responsibility because he has no need for it ... many people have describe God so fiercely for youth that they think if they criticize they turns into cockroach, why? Like an oppressive lord everyone has to kneel down to ... the society's God is a God who has imprisoned everyone ... everything is sinful in his eyes.'
\end{abstract}

(Participant in study)

Some participants claimed that this oppressive and despotic God had limited their social and individual liberty and thus, had made life harder for them. They felt that they were under the pressure of his many unacceptable desires in life, to the extent that one of the participants considered Satan as a break to reduce these pressures: 'Satan is not always so bad ... sometimes he's good for a break' (Participant in study).

It would seem that, with the existence of such a socially dominant God concept in the mentality of the youth, two different groups can be distinguished: 'related' and 'unrelated'.

'Related' are the people and groups in society who are matched with the concept of a dominant God in the society. They consider themselves good and religious people, who have a good relationship with God and therefore feel happy and comfortable in the society. However, some young people consider themselves 'unrelated' and feel limited and oppressed. They feel they have to sacrifice their needs and desires because of this God and don't see this God as responding to their needs and desires. Consequently, they don't see this God on their own side as a companion. They think a relationship with this God is obtained through religious rituals and duties in a specific framework. It seems that in this formal and stereotypic relationship, God and human being have two completely different identities. The external and internal God, the individual God and the social God are different in a way that God is actually the 'other': 'The society shows a distant and inaccessible image of God ... In society it is implicated that he is God and you are a human'.

The consequences of such conceptions of God is the formation of the concept of a 'marginal' and 'situational' God, especially for those who are not able to or do not have the opportunity to have a positive image of God through a spiritual and personal experience. Their knowledge of and relationship with God has only been formed through these socially dominant images and conceptions of God. The marginal and situational God is only remembered in critical and specific problems and crises. He has a weak presence in both their private and individual life. Moreover, this image of God has other negative consequences, including:

- the fear of and detachment from God and religion among youth

- lack of real knowledge of God

- more tendency in youth towards religious or ethical deviations such as Satanism
- hopelessness and despair

- depression

- feeling under pressure

- internal and social insecurity

- carelessness to life and lack of having positive goals in life

- assuming God as an enemy

- alienation

- considering religious social classes as low classes

- distrust to religious sources of imitation.

It would seem that inner and internal insecurity is caused by an intense feeling of guilt and oppositions between the inside and outside and the external insecurities are caused by social restrictions and pressures. Therefore, a considerable gap and detachment is created between the public and private space of people's lives and the society tends towards secularisation from the inside. Some of the youth believed our society had lost its faith and that God's real presence was weakly felt in social environments:

'In our society many people don't actually know God, we have lost our faith ... people have really forgotten God ... In Iran's present society God is rarely seen'.

(Participant in study)

The conditions of modernity in Iran's society have contributed to creating a gap and contradiction between the concept of the internal and external God. Modern media, familiarity with a variety of religions and cultures, the expansion of the culture of consuming and tendency towards fashion and also the growth of modern education and rationalism are all factors that force the youth towards critical thinking and reflection about religion and the concept of the socially dominant notions of God. One of the most important effects of modernity on the concept of God in the mentality of the youth is their tendency towards pluralism:

'All the followers of other religions are not pagan ... Anyone who's really close to God has a real religion ... are religions are complete and good for themselves and have to be respected'.

(Participant in study)

They believe all worshipers of God and divine religions have to be respected. Many of the youth who participated in this research accepted the variety of existing beliefs and believed that real faith is having a spiritual relationship with God, not just following specific, religious instructions.

\section{Conclusion}

The aim of this article was 'the conceptual reconstruction of the concept of God in the mentality of youth'. The concept of God is fundamentally important in the sociology of religion, is part of our everyday consciousness and expresses our meaning systems. Questioning about God is questioning about human identity. The concept of God reflects values, norms, laws, family and educational system relationships and also the social and political power structure. The results of this study showed three domains regarding the concept of God, 'epistemological', 'emotional' and 'social interaction'. In the epistemological domain, the existence of mental restrictions that are rooted in cultural beliefs and religious socialisation, have deprived the youth of the possibility to 
question and intellectually discover God. On the other hand, modernity and globalisation have created new chances and opportunities for the youth, which in turn can have positive or negative consequences. The result of these evolutions is the existence of various and plural conceptions of God and also the growth of criticising and rational approaches. In any case, it seems that in assessing the concepts of God in the domain of rationality is much more limited and fainter than the emotional. Also, anthropomorphic concepts and the individual and personal concept of God have strong emotional aspects and dimensions. But a spiritual (emotional) relationship with God gives believers strong social identity and they feel comfortable within the religious group fraternity. In religion, one uses one's body as a tool during this brief stopover on earth, preparing for the safe journey hereafter to some unknown heavens, by praying to supernatural powers. But as the religious path to happiness is incompatible with postmodern life-sciences, biology and physiological psychology and it overlooks life's reproduction, social interdependence and work-action, anthropologists and social scientists find little significance in the study of religion. As God Almighty is perfect, he seems uninvolved with this imperfect world order relating to social, economic and scientific issues. Nonetheless, this article could not determine the religious factors that lead to chauvinism, hatred, gender discrimination, cruelty, violence and suicidal killings in the name of God.

\section{References}

Armstrong, K., 1993, A History of God, Ballantin Books, New York. Backford, J.A., 2003, Social Theory \& Religion, Cambridge University Press, Cambridge, UK.
Berger, P.L., 1976, The Social Reality of Religion, Faber and Faber, London.

Berger, P.L. \& Luckman, T., 1967, The Social Construction of Reality: A Treatise in the Sociology of Knowledge, Doubleday, New York.

Bowker, J.W., 1973, The Sense of God: Sociological, Anthropological, and Psychological Approaches to the Origin of the Sense of God, Clarendon Press, Oxford.

Bunge, M., 1998, Social Science Under Debate: A Philosophical Perspective, University of Toronto, Toronto.

Creswell, J.W., 1994, Research Design, Sage, London.

Foran, J., 1993, Fragile Resistance: Social Transformation in Iran from 1500 to the Revolution, West view Press, Boulder.

Fromm, E., 1967, Psychoanalysis and Religion, Yale University Press, New Haven.

Griffin, D.R., 1989, God and Religion in the Postmodern World: Essays in Postmodern Theology, SUNY, Albany.

Hall, S. \& Gieben, B. (eds.), 1992, Formations of Modernity, Polity Press, Cambridge. Hall, S. \& Held, D., 2003, Modernity and Its Futures, Polity, Cambridge.

Hamilton, M.B., 2001, The Sociology of Religion: Theoretical and Comparative Perspectives, Rutledge, London.

Odwazny Peterson, A., 2005, The Dynamic God Image: Psychoanalytic Object Relational, Developmental and Jungian Theories of God Image and Their Implications for Psychotherapy, Institute of Integral Studies, San Francisco, CA.

Ritzer, G., 2006, Contemporary Sociological Theory and Its Classical Roots: The Basics, McGraw- Hill, Boston, MA.

Spuler, B. \& Kissling, H.J., 1995, History of the Muslim World, Markus Wiener Press, Michigan.

Stark, R., 2003, '"Why Gods Should Matter in Social Science"', Chronicle Review 49, B4.

Stark, R., 2003, For The Glory of God: How Monotheism Led to Reformations, Science, Witch-Hunt, and The End of Slavery, Princeton University Press, Princeton, New Jersey.

Strauss, A.L. \& Corbin, J., 1998, Basics of Qualitative Research, Sage, London.

Warrick, sr.E.L., 1999, 'The Influence of God Concept in Differentiation of Social and Political Attitudes', viewed 27 February 2010, from www.infuence of god concepts.blogspot.com

Young, T.R., (1992), 'Postmodern Understanding of The God Concept: Social Justice and The Drama of The Holy', in The Holy of God, viewed, n.d., from http:// uwacadweb.uwyo.edu.

Ziebertz, H.G., 2001, The Human Image of God, BRILL Press, Leiden. 